\title{
QUESTIONNAIRE-BASED PRONUNCIATION STUDIES: ITALIAN, SPANISH AND POLISH STUDENTS' VIEWS ON THEIR ENGLISH PRONUNCIATION
}

\author{
MARTA NOWACKA \\ University of Rzeszów
}

\begin{abstract}
This article is an attempt to review the most recent phonetic literature on the application of questionnaires in phonetic studies. In detail, we review the scope of pronunciation questionnaire-based surveys with respect to Polish and non-Polish students of English. In addition, this paper aims to examine European students' beliefs and attitudes towards their own English pronunciation and is also intended to provide some arguments for or against the use of foreign-accented rather than native models of pronunciation in phonetic instruction.

The data come from three groups of informants, namely: Italian, Spanish and Polish students of English. With respect to foreign, non-Polish respondents, the study was conducted at the University of Salento in Italy and the University in Vigo, Spain within the framework of the Erasmus Teacher Mobility Programme in two consecutive academic years: i.e. 2010/2011 and 2011/2012. As regards Polish respondents, our research involved subjects from six different tertiary schools, i.e. five universities and one college, located in various parts of Poland.

On balance, the results of our study give an insight into the phonetic preferences of adult European advanced students of English with reference to the importance of good native-like pronunciation, the aims of pronunciation study, factors contributing to phonetic progress and their self-study pronunciation learning strategies. Our findings point to the fact that students of English wish to speak with good pronunciation, set a high native-like standard for themselves, report having benefited from their phonetic instruction and exposure to native English and that they work on their pronunciation by means of various, mostly cognitive, strategies.

Rather than casting new light on teaching pronunciation, the outcome of this study is consistent with the findings of other research on foreign students' choice of preferred pronunciation model, which is undeniably native rather than foreign-accented.
\end{abstract}

\section{Introduction: the outline of questionnaire-based studies}

A common method of eliciting learners' judgments on various aspects of language teaching and learning is the use of questionnaires. In the phonetic literature a wide array of questionnaires concerning pronunciation can be found. Although it is claimed that they are not reliable, since they present the respondents' subjective opinions and judgments about the situation rather than the bare facts themselves, they are a frequently used assessment tool as they provide valuable feedback to teachers. Anybody willing to 
make use of an opinion survey should consult Dörnyei's (2003) and Presser et al.'s (2004) publications about the nature, the merits and the shortcomings of questionnaires. In addition, Dörnyei (2003) discusses their construction and administration and the processing of questionnaire data. Moreover, Presser et al. (2004), apart from covering topics of current research, examine practical interests in questionnaire survey methodology and sampling.

Thus, numerous publications present the results of such surveys of opinions. For the purpose of this analysis we have examined about fifty questionnaire-based pronunciation studies and divided them into two groups, i.e. firstly, the surveys that focus on international informants and then the ones that concern Polish respondents exclusively. The former studies, conducted on the international scene, concentrate on different aspects of pronunciation education, researching, for instance:

- attitudes to pronunciation in $\mathrm{EFL}^{1}$ (Porter and Garvin 1989);

- attitudes to foreign accent or native-likeness in the L2; pronunciation selfevaluation (Hammond 1990);

- the importance of 'good pronunciation' (Kenworthy 1990);

- phonology in teacher training courses (Bradford and Kenworthy 1991);

- factors affecting pronunciation learning (Edwards 1992 as cited in Barrera Pardo 2004);

- knowledge of English pronunciation, motivation and self-awareness (CelceMurcia et al. 1996);

- the content of phonology courses in the USA (Murphy 1997);

- motivation in pronunciation (Dalton and Smit 1997);

- students' awareness of the difficulty and importance of English pronunciation; influential factors in the acquisition of pronunciation; attitudes towards English accents (Cenoz and Garcia-Lecumberri 1999);

- teaching intonation among EFL practitioners (Roads, 1999);

- proclaimed and perceived wants and needs among Spanish teachers of English (Walker 1999);

- pronunciation learning styles (Basso 2000);

- the effectiveness of teaching pronunciation to Malaysian TESL students (Rajadurai 2001);

- pronunciation views and practices of reluctant teachers in Australia (MacDonald 2002);

- native speaker norms and International English (Timmis 2002);

- learners' ethnic group affiliation and L2 pronunciation accuracy; native-like nonaccented L2 speech (Gatbonton et al. 2005);

- links between pronunciation teaching, EIL and the sociocultural identity of nonnative speakers of English; awareness of EIL-related matters (mutual intelligibility in non-native to non-native communication) (Sifakis and Sougari 2005);

\footnotetext{
${ }^{1}$ All the abbreviations that are included in this paragraph are explained here: EFL - English as a Foreign Language, L2 - second language, TESL - Teaching English as a Second Language, EIL - English as an International Language, ESP - English for Specific Purposes.
} 
- international students' attitudes towards English pronunciation and the comparison of Euro-English with the Lingua Franca Core (Bryła 2006);

- students' evaluation of learner corpora in L2 prosody research and teaching (Gut 2007);

- perception of foreign accent by native and non-native speakers (Vishnevskaya 2008);

- personality traits (extroversion, empathy etc.) and pronunciation talent in L2 acquisition (Hu and Reiterer 2009);

- musicality and the phonetic language aptitude (Nardo and Reiterer 2010);

- pronunciation preferences for phonological variation among linguistically trained and untrained respondents (Benrabah 2010);

- native and non-native perception of foreign-accented speech (Nowacka 2010);

- students' attitude toward pronunciation: the perceived utility of pronunciation, level of confidence and interest in pronunciation, teachers' views and practices with regard to pronunciation instruction (Yeou 2010);

- English pronunciation teaching practices in European countries/survey (Henderson, in press; Henderson and Frost et al. in press);

- pronunciation identity constructions of learners and speakers among Croatian students (Josipović Smojver and Stanojević, in press);

- the phonetic needs of French EFL students (Nasser-Eddine, 2011);

- students' metacognitive awareness; pronunciation learning strategies (Murphy, in press);

- EFL pronunciation attitudes: standard Croatian, self-assessment of English pronunciation, perceived role in the exchange (Stanojević et al., in press);

- the changing attitudes to accents in professional discourse of learners of ESP (Tyurina and Koltzova, in press);

- French students' familiarity with, and attitudes towards, other foreign accents in English (Scheuer, in press);

- and teaching pronunciation in EFL classes (Luke [nd]) to give some examples of such studies.

Some questionnaires have been administered solely to Polish students of English in order to examine their views on different aspects of phonetic instruction. The most frequently discussed issue concerns the teaching and learning of English phonetics at schools of higher education, i.e. universities and colleges (Waniek-Klimczak 1997; Dziubalska-Kołaczyk et al. 1999; Sobkowiak 2002; Wysocka 2003; Wrembel 2005) as well as at secondary schools (Szpyra-Kozłowska et al. 2002; Wrembel 2002).

Other fields of interest within phonetics comprise:

- students' attitudes to teaching suprasegmental phonetics on the basis of authentic texts (Pospieszyńska and Wolski 2003);

- the role of metacompetence in the acquisition of FL phonology (Wrembel 2003);

- phonetic transcription (Ciszewski 2004);

- students' judgments of the English pronunciation model (Szpyra-Kozłowska 2004);

- the goals of L2 pronunciation instruction; subjects' attitudes to native speaker varieties and their perception of speech with disturbed rhythm (Janicka 2005); 
- phonetic learning preferences in relation to field dependence and independence (Baran 2006);

- features which condition success in the acquisition of English phonetics (Gonet 2006);

- the use of the language laboratory in modern pronunciation pedagogy (SzpyraKozłowska et al. 2006);

- pronunciation learning strategies with a focus on advanced students (Pawlak 2006, 2008, 2010, in press);

- attitudes to native English accents as models for EFL Pronunciation (Janicka et al. 2008);

- pronunciation self-evaluation (Nowacka 2008);

- target in speech development: the choice of model, accent preferences, the attainment of native-like accent, the role/importance of pronunciation as a subskill in communication (Waniek-Klimczak and Klimczak 2008)

- and attitudes to male and female voices (Szpyra-Kozłowska and Pawlak 2010).

To sum up, a wide array of pronunciation-related topics have been researched with the use of questionnaires. Thanks to the data collected in them, teachers and researchers can formulate some generalizations about, for instance, students' phonetic preferences, which are the centre of attention in this analysis.

\section{Experimental design}

In this section the aims of the study, the questionnaire design, respondents and questionnaire administration are presented.

\section{The aims}

Although, as has been demonstrated in the preceding section, students' views on English pronunciation have been studied in several questionnaires, for the purpose of this analysis we felt it necessary to examine international, i.e. Italian, Spanish and Polish, students' phonetic preferences. We examine and compare four aspects of their pronunciation teaching and learning, namely: the importance of good native-like pronunciation, the aims of pronunciation study, factors contributing to phonetic progress and self-study pronunciation learning strategies.

There is also a secondary aim to this study, namely to provide an argument in the discussion about changing models of pronunciation, e.g. EIL/LFC on the basis of students' preference for or disregard of native standards. This intention was triggered by Remiszewski's (2008) call for such investigations:

The debate [how to teach pronunciation in the EFL classroom] must embrace the attitudes and beliefs of the learner. Paradoxically, proposals centered around LFC are claimed to be designed for the learner's benefit, but at the same time we still know so little about the learner's actual point of view. This must change, as the data which are already available show that a more thorough analysis of learners' motivations and beliefs can cast some new light on the discussed problem. As for now, the picture is far from complete." (Remiszewski, 2008: 307) 


\section{Questionnaire design}

The questionnaire was designed for the purpose of my $\mathrm{PhD}$ in the year $2004 .^{2}$ It contained seven questions, both open and closed, which initially the Polish informants were asked to answer. The results concerning the first four questions are reported below and then followed by a discussion of several pertinent issues that emerged from their analysis.

\section{Respondents and questionnaire administration}

157 students of English, from three different countries, i.e. Italy, Spain ${ }^{3}$ and Poland, took part in this project. The Polish students made up the majority (58\%), the remaining $42 \%$ was shared by the Italians $(24 \%)$ and the Spanish (18\%).

The data on the Italian respondents were collected at the University of Salento, Lecce, in the south of Italy, in April 2011. The informants were all second year students of the Faculty of Modern Arts (Facolta di Lettere Moderne). Most of these 38 participants were female (35), with a mean age of 20.5. They had been learning English for about 11.5 years and their proclaimed level of advancement in English was on the whole intermediate $(87 \%)$.

As regards the survey administration in Spain, in October 2011, the questionnaire was conducted with 28 second year students of the University of Vigo, in the northwestern part of Spain, in the Faculty of Translation. Females constituted the majority (68\%). The students' mean age was 20. Their declared length of studying English was 14 years and they mostly regarded themselves as upper-intermediate $(61 \%)$ and advanced students $(36 \%)$. Thus, their level of proficiency was one stage higher than that of the Italians'.

When it comes to the Polish informants, the data were gathered in the year 2004 . Unlike previous studies of this kind, our research involved subjects from six different tertiary schools (five universities and one college), located in various parts of Poland in Kraków, Lublin, Łódź, Poznań and Sosnowiec and also at the college in Rzeszów. ${ }^{4}$ A total of 91 Polish tertiary school students of English, who were randomly selected at the respective centres, participated in the study. They are regarded to be a homogenous group as all of them were final year students of English. University students (62) were in the majority, constituting $68 \%$ of the subject population under study, while college subjects (29) were in the minority, i.e. 32\%. These informants reflect the student population of English at tertiary schools quite well since female students $(70,77 \%)$ outnumbered their male counterparts $(21,23 \%)$ as they usually do.

\footnotetext{
${ }^{2}$ The experiment, which consisted of a written questionnaire and a recording of reading and spontaneous speech, was conducted during the summer term, over a period of two months, from March to April 2004. In this article only some written data are discussed. The analysis of the recording, the students' self-evaluation of their pronunciation, native and non-native ratings of the subjects' phonetics are presented in Nowacka (2008).

${ }^{3}$ The visit within the Erasmus Teacher Mobility Programme.

${ }^{4}$ The experiment was held at the following universities: Jagiellonian University in Kraków (14 respondents), Maria Curie-Skłodowska University in Lublin (11), The University of Łódź (10), Adam Mickiewicz University in Poznań (12) and The University of Silesia in Sosnowiec (15) along with one college, the Teacher Training College of Foreign Languages in Rzeszów (29).
} 
To recap, we present the results of the questionnaire conducted with 157 subjects of three nationalities in order to formulate some conclusions on international students' phonetic wants and needs.

\section{Results and discussion}

This section discusses the results corresponding to each questionnaire statement in the order in which they appeared in the survey.

\subsection{Importance of good English pronunciation}

At first, the respondents were asked to take a stance on the problem expressed in the following statement "It is important for me to have good English pronunciation." Their task was to gauge its importance on a 5-point scale, i.e. "strongly agree - agree undecided - disagree - strongly disagree" The notion of 'good' was not defined as it was the informants' task to decide what it meant for them. In this respect the survey has confirmed the obvious, which can be seen in Figure 1.

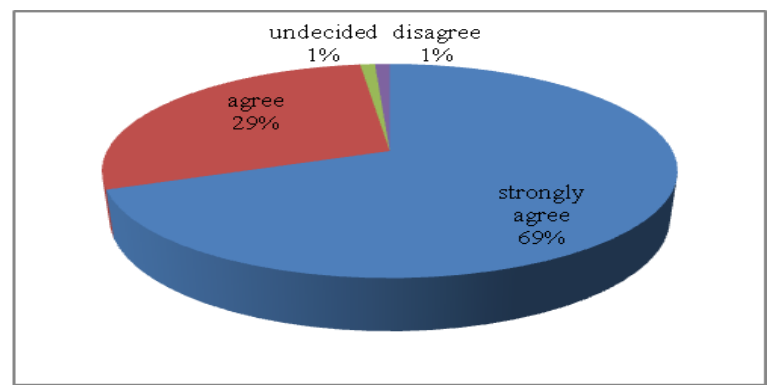

Figure 1: Statement 1: "It is important for me to have good English pronunciation."

Almost all respondents (98\%) have positive beliefs regarding the importance of speaking English with good pronunciation. To be more precise, $69 \%$ strongly agreed with this statement; the rest $(29 \%)$ chose a more moderate option by ticking the answer 'I agree' while the remaining $2 \%$ chose the 'undecided' and 'disagree' option.

After choosing an answer, the subjects were to give reasons for their choice. To justify their opinion, the informants supplied arguments which can be grouped into three major categories. According to some of them, it is important to have good English pronunciation in order to: sound like a native/near-native speaker, to be clearly understood/to communicate successfully/to avoid misunderstandings as well as to be a good model for students as a teacher, and to clients as an interpreter, in the future.

To conclude this section, it should be stated that in general, a positive picture emerges from this set of responses since nearly all students of English consider it important to speak English with good pronunciation. In general, the reasons for such an opinion are as follows: they wish to sound native-like, want to be clearly understood or 
simply feel that good pronunciation should be part and parcel of their professional qualifications.

\subsection{Aims of the pronunciation study}

The second questionnaire point sought to obtain the respondents' opinions as to the following statement: Students should aim for native English pronunciation. ${ }^{5}$ Figure 2 shows the obtained results.

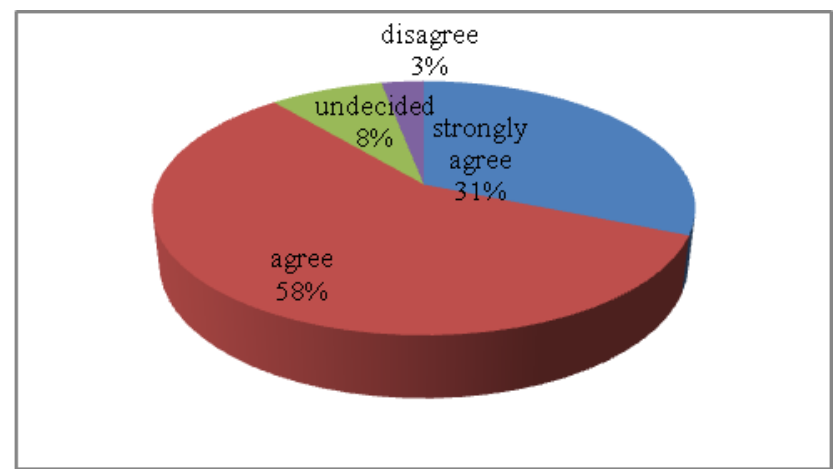

Figure 2: Statement 2: "Students should aim for native English pronunciation."

It is clear that the majority of students (89\%) agree with this statement, with $31 \%$ opting for 'strongly agree' and 58\% for 'agree.' The remaining $8 \%$ are undecided as to whether native English should be a goal of pronunciation education, and 3\% disagree with such an idea. Thus, in all likelihood we can predict that most of them would aspire to the native or near-native model of pronunciation in their speech.

Additionally, in order to see whether native-like pronunciation rather than EIL is favoured by students, we rephrased the afore-mentioned statement in a different way, i.e. we referred to the informants' choice of pronunciation "I attempt to speak with native English pronunciation." Figure 3 presents the obtained results, which prove that the majority of the students, i.e. $86 \%$ of Spanish and $84 \%$ of Italians, wish to speak with native pronunciation. No statistically significant differences between the examined nationalities can be found here.

\footnotetext{
${ }^{5}$ Similarly to question 1 , the same 5-option continuum was used to obtain responses.

${ }^{6}$ This statement was tested only with Italian and Spanish subjects.
} 


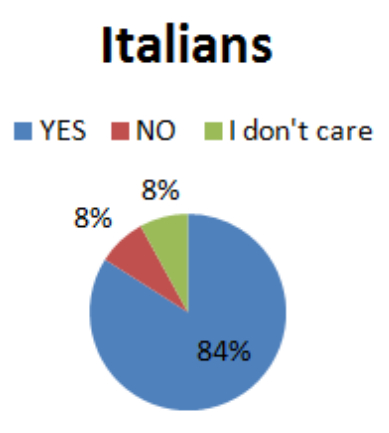

\section{Spanish}

aES $\square$ NO $\quad$ Idon't care

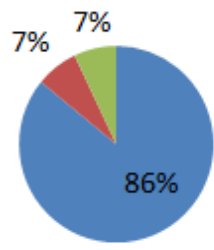

Figure 3: Statement: "I attempt to speak with native English pronunciation" tested with Italian and Spanish respondents.

To sum up, it should be noted that the majority of the students in this study maintain that they aim for native English pronunciation. What we have learnt from the respondents' justifications is that they assume that nativelikness should be the target for language specialists and other learners' pronunciation should be intelligible enough to allow them to communicate. We have also noted a few voices stating that native-like pronunciation increases one's chances of finding a good job in the European Union, and one dissenting voice saying that accent-free English speech deprives a foreigner of his/her own identity.

\subsection{Factors contributing to phonetic progress}

Responses to question 3 were to supply information on the factors which have a major influence on the informants' pronunciation. Figure 4 summarises the results.

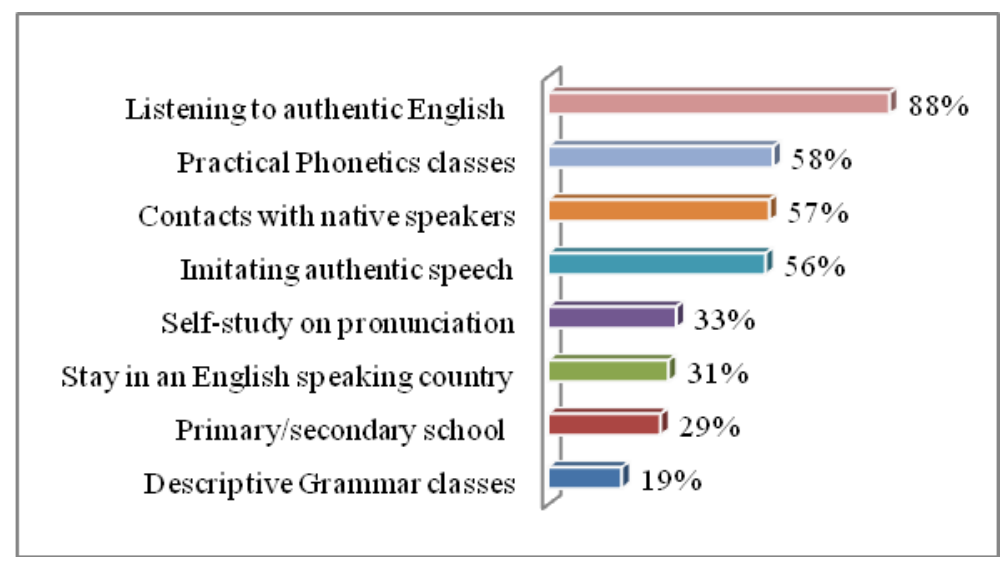

Figure 4. Response to question no. 3: What factors have contributed to improving your English pronunciation most? 
As can be seen from Figure 4, 'listening to authentic English' (88\%) is claimed to be the most beneficial factor which has contributed to improving students' pronunciation most. The ranking of the remaining factors, from the most to the least useful ones is as follows: practical phonetics classes (58\%), contacts with native speakers $(57 \%)$, imitating authentic speech (56\%), self-study on pronunciation (33\%), stay in an English speaking country (31\%), primary/secondary school English teacher's classes (29\%) and 'Descriptive Grammar' classes (19\%).

\subsection{Pronunciation self-study and pronunciation learning strategies (henceforth PLS)}

The next questionnaire task, expressed in question 4, Have you ever worked on improving your pronunciation on your own outside the classes? was intended to reveal whether or not the respondents have ever made a self-initiated conscious effort at improving their pronunciation outside phonetic training at their tertiary school. The obtained figures are encouraging, with $3 / 4(76 \%)$ of the respondents claiming to have worked on pronunciation on their own, and only $1 / 4(24 \%)$ admitting that they have never done so.

Those who acknowledge self-practice of pronunciation were further asked to reveal how they do it. The respondents report having used a wide variety of self-study techniques since they list as many as 37 different strategies. A lot of these techniques are very similar and might be grouped into more general categories of the traditional 'listen and repeat' type. Most students specify more than one form of self-practice (averaging 1.6). The most popular PLSs mentioned by students are: reading aloud to oneself (9\%), listening to and imitating authentic speech (8\%), drilling difficult words and utterances, making use of transcription and checking the pronunciation of words in dictionaries.

To classify PLS we found it convenient to follow the taxonomy created by Pawlak (2010), thanks to which cognitive, metacognitive, social and affective strategic devices could be distinguished. It turned out that cognitive strategies were the most frequently applied by our subjects (27 PLSs). According to Pawlak's (2010:195): “(...) the group of cognitive PLS is by far the most elaborate, both with respect to the sheer number of strategic devices and their specificity, which is fully warranted by the fact that it contains actions and thoughts which are directly involved in studying and practising target language pronunciation, thus constituting the core of the whole classification scheme." The cognitive strategies were then followed by 7 metacognitive techniques ${ }^{8}$, namely: 'recording oneself', 'practising pronunciation of separate words and sounds', 'recording oneself on a tape and then listening and making corrections', 'self-monitoring', 'listening to pronunciation (paying attention to it while listening to authentic English)', 'recording BBC news and then recording oneself and comparing one's pronunciation with the original', 'writing down a tapescript with a focus on unfamiliar sounds and words'. Among the responses there were also 3 social strategies such as 'talking to a non-native speaker who knows the language and has better pronunciation than me',

\footnotetext{
${ }^{7}$ By 'Descriptive Grammar classes' I meant the theory of phonetics and phonology.

${ }^{8}$ Some of these 'metacognitive' strategies overlapped to some extent with 'cognitive' ones.
} 
'talking to other students' and 'attending conversation classes with American native speakers'. Not even one respondent pointed to affective strategies which involve such things as rewarding and/or encouraging oneself or the use of relaxation techniques. The above-mentioned findings are consistent with the results of other researchers (cf. Droździał-Szelest 1997; Petersen 2000 as cited in Pawlak 2010:198; Pawlak 2008, 2010).

Cognitive PLS were the winners. Respondents reported the use of 27 different strategies. These strategies correspond to some extent to the skills of listening, speaking and reading or the skills combined. The respondents' pronunciation techniques based on listening enhanced by other activities are as follows: listening to BBC (on the radio), authentic English (on TV), English songs and films; listening to and reading (BBC English) materials; listening to (English) tapes/BBC World on the radio and repeating after a model/imitating the speaker/authentic speech, as well as watching English language programmes. The skill of speaking and in particular work on correct articulation of English could be what our informants had in mind when they reported: imitating authentic speech (audio books, films etc.)/native speakers; practising along with films; singing songs in English (simultaneously with the singer on the CD); talking to British friends/oneself in English; conversing in English with foreign students while staying abroad; speaking aloud (revision before exams); murmuring to oneself and even drilling particular words/groups of words "which I found difficult"/repeating certain words and phrases/authentic utterances. Some responses point to the subjects' use of different sources of educational materials, e.g. studying pronunciation with books, tapes and phonetic transcription of words; checking pronunciation (of unknown words) in a dictionary and then pronouncing them aloud/working with some pronunciation dictionaries; using original tapes with English pronunciation/practical phonetics textbooks /doing some activities; doing pronunciation exercises on the Internet. One of the respondents mentioned reading aloud (to oneself) and yet another identified staying in an English-speaking country and 'absorbing' the language as one of their pronunciation learning strategies.

This outcome to some extent confirmed the obvious, as Pawlak (2010: 191-192) points to their similar ranking: “. . in the group of direct PLS, it is cognitive strategies, such as naturalistic and formal practice or attempts to analyze the sound system that are likely to play the most significant role. (...) [indirect] strategic devices will probably be utilized less frequently than direct ones (...) with learners opting mainly for metacognitive strategies (e.g. planning for a language task or self-evaluation) rather than social (e.g. asking a classmate to correct one's pronunciation) or affective ones (e.g. encouraging oneself to practice new sounds)."

On the whole, subjects have pointed to some time-consuming but beneficial methods like recording oneself followed by a detailed analysis of the outcome and self-correction. They see the importance of pronunciation self-study, realize that formal phonetic classroom training is insufficient, they work on pronunciation on their own, and they report using numerous and varied self-study pronunciation strategies, mostly cognitive ones.

\footnotetext{
${ }^{9}$ Direct PLSs are the ones that require mental processing of language, while indirect PLSs are those that support learning in general and do not have to involve target language use.
} 


\section{Statistical analysis}

The application of Pearson's Chi-square Test for Independence has allowed us to measure if the dependencies between the nationality and the examined variables concerning pronunciation are statistically significant. ${ }^{10}$

The results suggest that the respondents' nationality does not affect the first two variables, i.e. "It is important for me to have good English pronunciation" ( $\mathrm{p}>\alpha$, $\mathrm{p}=0.55535$ ) presented in Figure 5 and "Students should aim at native English pronunciation" $(p>\alpha, p=0.52756)$ shown in Figure 6. In other words, the distribution of responses to the above-mentioned statements is similar regardless of students' nationality.

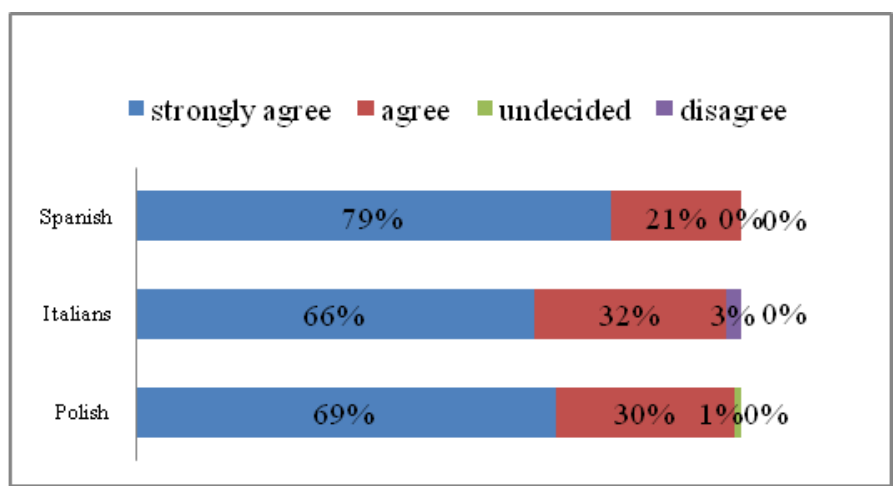

Figure 5. Nationality versus good pronunciation.

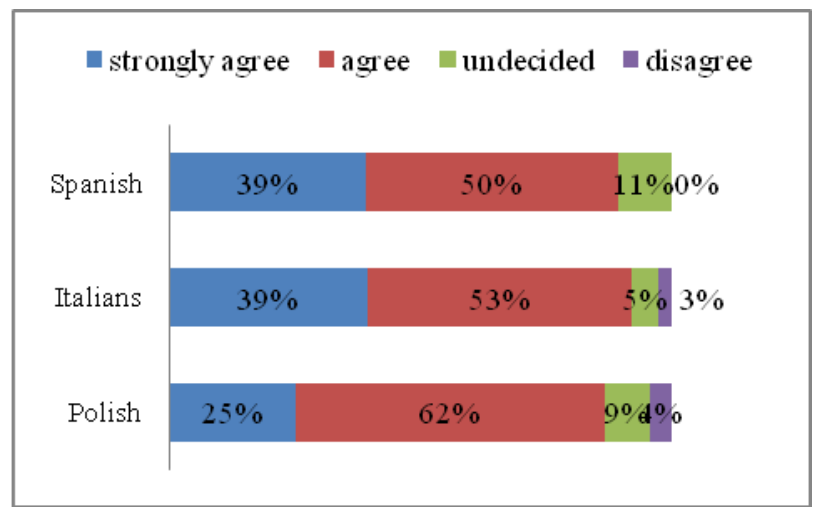

Figure 6. Nationality versus native English pronunciation.

${ }^{10}$ The significance level selected for this study is $\alpha=0.05$. It is assumed that when:

a) $\quad p<0.05$ there is a statistically significant dependency (marked with*);

b) $\quad p<0.01$ there is a highly significant dependency (marked with**);

c) $\quad p<0.001$ there is a very high significant dependency (marked with $* * *$ ). 
However, as can be seen in Figure 7, the test has proved that there is a dependency between the respondents' nationality and pronunciation self-study $(p<\alpha, p=0.01249)$. Even if we look at the percentage we can see that the Italian respondents' responses (58\% 'yes'; 42\% 'no') differ from the ones given by the Spanish (82\% 'yes'; 18\% 'no') and Polish (81\% 'yes'; 19\% 'no') subjects.

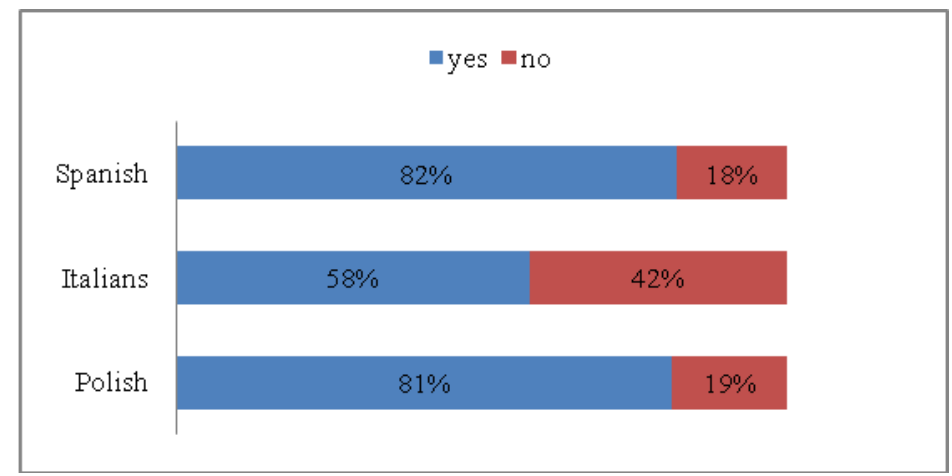

Figure 7. Pronunciation sulf-study.

As regards the dependencies between nationality versus the factors most influencing the respondents' pronunciation we could observe differences in the case of five out of eight factors; namely, stays in an English speaking country $\left(\mathrm{p}=0.02196^{*}\right)$, contacts with native speakers $\left(\mathrm{p}=0.01813^{*}\right)$, practical phonetics classes $\left(\mathrm{p}=0.00000^{* * *}\right)$, imitating authentic speech $(\mathrm{p}=0.00002 * * *)$, and primary/secondary school English $(\mathrm{p}=0.00000 * * *) .{ }^{11}$ The differences in percentages among the nationalities can be seen in Figure 8.

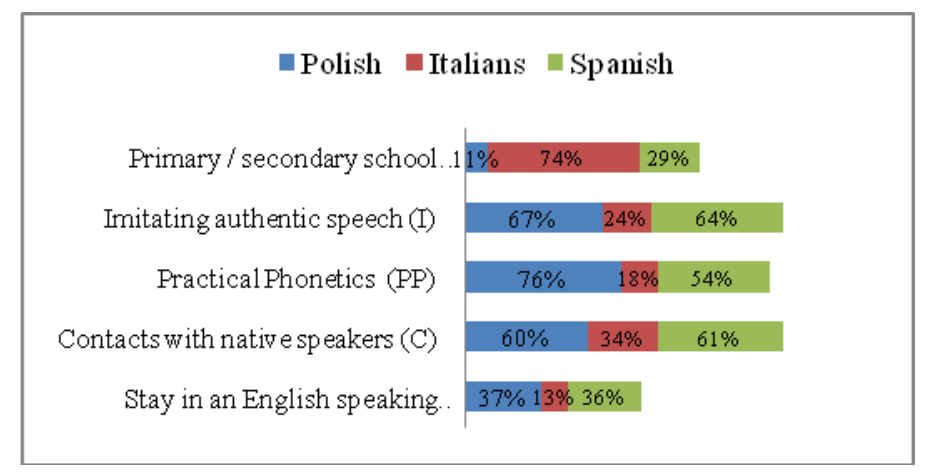

Figure 8. Nationality versus self-study pronunciation strategies.

${ }^{11} \mathrm{p}>\alpha$ for the remaining three factors was calculated as follows: self-study on pronunciation $(\mathrm{p}=0.40755)$, 'Descriptive Grammar' classes $(\mathrm{p}=0.29020)$ and listening to authentic English $(\mathrm{p}=0.05135)$. 
We have also examined the ranking of these influential factors for individual nationalities. For all the examined nationalities 'listening to authentic English' occupies the top position, then the ranking of factors differs slightly. For instance, the Italian respondents regard 'primary and secondary school education' as the second most beneficial aspect. The Spanish value 'contacts with native speakers' and 'practical phonetics' next while Poles opt for 'practical phonetics,' 'imitating authentic speech' as well as 'contacts with native speakers'.

\section{Conclusions}

This article was intended to provide a thorough examination of the nature of pronunciation preferences of Italian, Spanish and Polish learners of English. The survey conducted by the present author reveals that most students wish to speak with good English pronunciation and to sound native-like, which agrees with the findings by Porter and Garvin (1989), Waniek-Klimczak (1997), Szpyra-Kozłowska (2004), Bryła (2006), Janicka et al. 2008, and Waniek-Klimczak and Klimczak (2008). The respondents believe it is important to have good pronunciation in English since they want to be clearly understood, serve as a good model for students and be perceived as competent users of English. The majority of informants agree with the statement that students should aim for native English pronunciation. Those who do not support this claim seem to regard intelligibility as the main aim of communication and take into account the needs of people who are not specialists in English.

Students report that their pronunciation has improved most as a result of listening to authentic English, practical phonetics instruction, imitating authentic speech as well as through contacts with native speakers. Waniek-Klimczak's (1997) subjects point to a slightly different order of factors which most influenced their pronunciation. Among them there are watching and listening to authentic English, practical phonetics and listening classes. One of our findings was that the college students favoured practical pronunciation classes over more academically-oriented 'Descriptive Grammar' classes, which is also consistent with Waniek Klimczak's (1997) results. However, in a survey by Dziubalska-Kołaczyk et al. (1999) a greater preference for 'Descriptive Grammar' is evident, although in general the majority of their subjects indicate a strong correlation between theoretical and practical classes and the positive influence of the two on their pronunciation. Furthermore, Cenoz et al. (1999) point to yet another ranking of factors beneficial for their students' phonetics, i.e. residence in an English-speaking country, speaking to natives, specific training through phonetics, listening to radio and TV and ear training.

The majority of our respondents $(76 \%)$ claim to study pronunciation on their own by means of different, mostly cognitive, strategies. This is a significantly higher percentage than that found by Sobkowiak's (2002) questionnaire, where only half of the experimental group claimed pronunciation self-study. The most frequently mentioned self-study techniques are as follows: reading aloud to themselves, imitating authentic speech from films, audio books and the media, listening to and repeating after a model, drilling particularly difficult words and phrases, learning pronunciation with books and 
tapes, working with pronunciation dictionaries as well as listening to and watching English-language programmes.

What agrees with the findings of Droździał-Szelest (1997), Petersen (2000 as cited in Pawlak 2010) and Pawlak (2006, 2008, 2010) is that most respondents tend to use traditional cognitive strategies such as repetition, and that transcription is also mentioned as a helpful tool in the mastery of pronunciation, which is also confirmed by Sobkowiak (2002). Unlike in Pawlak's (2006) research, the respondents in the present study are aware of the importance of comparing the authentic with the student's own speech. Metacognitive strategies such as self-evaluation and self-monitoring are also said to be employed.

To recapitulate, although this description of students of English is based on limited evidence, it is hoped that it provides a fair and adequate characterization of this group of learners with reference to their phonetic preferences. The results on students' wants and needs with respect to pronunciation point to the fact that learners of English wish to speak with good pronunciation, set a high native-like standard for themselves, report having benefited from their phonetic instruction and exposure to native English and that they work on their pronunciation by means of various, mostly cognitive, strategies.

The outcome of this study can serve as yet another argument for teaching native models of English to students of English (cf. Remiszewski 2008; Scheuer, 2008; Sobkowiak 2008; Szpyra-Kozłowska 2008). It is consistent with Sobkowiak's (2008:139) observation that among European students there is a preference for sounding native-like: "[q]uestionnaire and experimental research clearly shows that to most learners, at least in the European context, correct native(-like) pronunciation is not only a question of communicative pragmatics, but also self-image. And listeners, both native and non-native, evaluate the speaker on the basis of his pronunciation."

\section{References}

Baran, M. 2006. Phonetics learning preferences of Polish students. Field dependence, field independence as a moderate variable. In Dydaktyka fonetyki języka obcego $\mathrm{V}$ [Phonetics in Foreign Language Teaching 5], eds. W. Sobkowiak and E. WaniekKlimczak, 9-22. Płock: Wydawnictwo PWSZ.

Barrera Pardo, D. 2004. Can Pronunciation Be Taught? A Review of Research and Implications for Teaching. Revista Alicantina de Estudios Ingleses 17: 6-38 (http:,,publicaciones.ua.es,filespubli,pdf,02144808RD22945419.pdf) (date of access: 6 December, 2011).

Basso, R. 2000. Pronunciation: Student Awareness of Learning Styles. Speak Out! 26: 411.

Benrabah, M. 2010. English Pronunciation Preferences: Research by 'Indirect' Questionnaire. In English Pronunciation: Issues and Practices (EPIP): Proceedings of the First International Conference, ed. A. Henderson, 37-53. Chambery Cedex: Université de Savoie.

Bradford, B. and J. Kenworthy. 1991. Phonology on Teacher Training Courses, Speak Out! 9: 12-15. 
Bryła, A. 2006. European veto to the ideological assumptions of the LFC voiced by continental learners of English (survey analysis), In Dydaktyka fonetyki języka obcego $w$ Polsce VI [Phonetics in Foreign Language Teaching 6], eds. W. Sobkowiak and E. Waniek-Klimczak, 18-35. Konin: Wydawnictwo PWSZ.

Celce-Murcia, M., D. Brinton and J. M. Goodwin. 1996. Teaching Pronunciation: A Reference for Teachers of English to Speakers of Other Languages. Cambridge: Cambridge University Press.

Cenoz, J. and M. L. Garcia-Lecumberri. 1999. The acquisition of English pronunciation: learners' views, International Journal of Applied Linguistics 9: 3-15.

Ciszewski, T. 2004. Transkrypcja fonetyczna. Mity i uprzedzenia [Phonetic transcription. Myths and prejudice]. In Dydaktyka fonetyki języka obcego IV [Phonetics in Foreign Language Teaching 4], eds. W. Sobkowiak and E. WaniekKlimczak, 28-34. Konin: Wydawnictwo PWSZ.

Dalton, Ch. and U. Smit. 1997. On the motivation of advanced pronunciation learners. Speak Out! 21: 5-9.

Dörnyei, Z. 2003. Questionnaires in Second Language Research: Construction, Administration, and Processing. New Jersey: Lawrence Erlbaum Associates, Publishers.

Droździał-Szelest, K. 1997. Language learning strategies in the process of acquiring a foreign language. Poznań: Motivex.

Dziubalska-Kołaczyk, K., J. Weckwerth and J. Zborowska. 1999. Teaching phonetics at the School of English, AMU, Poznań, Poland. In Proceedings of Phonetics Teaching \& Learning Conference, 31-34. UCL, London, 14-15 April 1999,

http:,www.phon.ucl.ac.uk,home,johnm,poznan.htm (date of access: 26 March, 2007).

Edwards, M. 1992. Modelos lingüísticos de la enseńanza aprendizaje de segundas lenguas: la enseńanza-aprendizaje del sistema fonológico del inglés en hispanohablantes, In Bilingüismo y adquisición de lenguas: Actas del IX Congreso Nacional de AESLA, eds. F. Etxeberría and J. Arzamendi, 219-229. Bilbao: Universidad del País Vasco.

Fraser, H. 2001. Teaching Pronunciation: A handbook for teachers and trainers: Three frameworks for an Integrated Approach. New South Wales: Department of Education Training and Youth Affairs, DETYA, http:,,www-personal.une.edu.au, hfraser, (date of access: 26 March, 2007).

Gatbonton, E., P. Trofimovich and M. Magid. 2005. Learners' Ethnic Group Affiliation and L2 Pronunciation Accuracy: A Sociolinguistic Investigation, TESOL Quarterly 39, 3: 467-488.

Gonet, W. 2006. Success in the acquisition of English phonetics by Poles. A pilot study. In Dydaktyka fonetyki języka obcego w Polsce VI [Phonetics in Foreign Language Teaching 6], eds. W. Sobkowiak and E. Waniek-Klimczak, 70-88. Konin: Wydawnictwo PWSZ.

Gut, U. 2007. Learner corpora in second language prosody research and teaching. In Non-Native Prosody: Phonetic Description and Teaching Practice, eds. J. Trouvain and U. Gut, 145-167. Berlin: Mouton de Gruyter. 
Henderson, A. in press. The English Pronunciation Teaching in Europe Survey (EPTiES) and the collaborative generation of new knowledge, paper presented at Accents'2010: IV International Conference on Native and Non-native Accents of English, University of Łódź, 9-11 December 2010.

http:,,www.filolog.uni.lodz.pl,accents2010,Abstracts.htm\#smo) (date of access: 7 February, 2010).

Henderson, A., D. Frost, U. Cunningham, A. Kautzsch, A. Kirkova-Naskova, D. Levey, E. Tergujef and E. Waniek-Klimczak. in press. Joint Session on English Pronunciation Teaching in Europe Survey, paper presented at Accents' 2011: V International Conference on Native and Non-native Accents of English, Univeristy of Łódź, 15-17 December 2011.

$\mathrm{Hu}, \mathrm{X}$. and S. M. Reiterer. 2009. Personality and pronunciation talent in second language acquisition, In Language Talent and Brain Activity, eds. G. Dogil and S. M. Reiterer, 97-129. Berlin: Mouton de Gruyter.

Janicka, K. 2005. Pronunciation standards of English for non-native speakers of English: A case against Lingua Franca Core. Unpublished Ph.D. dissertation. Poznań: Adam Mickiewicz University.

Janicka, K., M. Kul and J. Weckwerth. 2008. Polish Students' Attitudes to Native English Accents as Models for EFL Pronunciation, In English Pronunciation Models: A Changing Scene, eds. K. Dziubalska-Kołaczyk and J. Przedlacka, 251292. Bern: Peter Lang.

Josipović Smojver, V. and M.-M. Stanojević. 2010. Stratification of EFL: identity constructions of learners and speakers, paper presented at: Accents' 2010: IV International Conference on Native and Non-native Accents of English, University of Łódź, 9-11 December 2010.

http:,,www.filolog.uni.lodz.pl,accents2010,Abstracts.htm\#smo (date of access: 7 February, 2010).

Keys, K. J. 1999. Making the right noises: pronunciation and teacher training in Brazil, Speak Out! 24: 40-44.

Luke, Ch. [nd]. Lesson plan for student teachers: creative ways of teaching pronunciation in FLE classes.

http:,www.edb.utexas.edu,field, seminar29.html (date of access: 26 March, 2007).

MacDonald, S. 2002. Pronunciation - views and practices of reluctant teachers, Prospect. Australian Journal of TESOL 17,3: 3-15.

Murphy, D. in press. Evaluation of a pedagogical model of L2 pronunciation learning: the case for a mixed methods approach, Abstracts 'Accents 2011': 17, paper presented at Accents' 2011: V International Conference on Native and Nonnative Accents of English, University of Łódź, 15-17 December 2011,

http:,filolog.uni.lodz.pl,accents2011,Abstracts.htm (date of access: 29 November, 2011).

Murphy, J. 1997. Phonology courses offered by METASOL programmes in the US, TESOL Quarterly 31: 741-764.

Nardo, D. and S. M. Reiterer. 2009. Musicality and the phonetic language aptitude. In Language Talent and Brain Activity, eds. G. Dogil and S. M. Reiterer (eds.), 213255. Berlin: Mouton de Gruyter. 
Nasser-Eddine, A. 2011. Second language acquisition: the articulation of vowels and the importance of tools in the learning process. In The Acquisition of L2 Phonology, eds. J. Arabski and A. Wojtaszek, 3-15. Bristol: Multilingual Matters.

Nowacka, M. 2008. Phonetic Attainment in Polish University and College Students of English: a Study in the Productive and Receptive Pronunciation Skills. Unpublished Ph.D. dissertation. Lublin: Maria Curie-Skłodowska University.

Nowacka, M. 2010. Native and Non-native Perception of Foreign-accented Speech: Do Polish and English raters have the same ear for nativelikness?. In Issues in Accents of English 2: Variability and Norm, ed. E. Waniek-Klimczak, 61-96. Newcastle upon Tyne: Cambridge Scholars Publishing.

Pawlak, M. 2006. On the use of pronunciation learning strategies by Polish foreign language learners. In Dydaktyka fonetyki jezzyka obcego w Polsce VI [Phonetics in Foreign Language Teaching 6], eds. W. Sobkowiak and E. Waniek-Klimczak, 121135. Konin: Wydawnictwo PWSZ.

Pawlak, M. 2008. Another look at the use of pronunciation learning strategies: an advanced learner's perspective. In Issues in Accents of English, ed. E. WaniekKlimczak, 304-322. Newcastle upon Tyne: Cambridge Scholars Publishing.

Pawlak, M. 2010. Designing and piloting a tool for the measurement of the use of pronunciation learning strategies, In Research in Language: Special Issue on Researching Variability and Teaching Accents of English 8, eds. E. WaniekKlimczak and L. Shockey, 189-202. Łódź: Łódź University Press.

Pawlak, M. in press. The use of questionnaires in research on learning and teaching second language pronunciation, Abstracts 'Accents 2011': 25, paper presented at Accents' 2011: V International Conference on Native and Non-native Accents of English, University of Łódź, 15-17 December 2011, http:,filolog.uni.lodz.pl,accents2011,Abstracts.htm (date of access: 29 November, 2011).

Peterson, S. 2000. Pronunciation Learning Strategies: A first look. Unpublished research report. (ERIC Document Reproduction Service ED 450 599, FL 026 618).

Porter, D. and S. Garvin. 1989. Attitudes to Pronunciation in EFL. Speak Out! 5: 8-14.

Pospieszyńska, M. and B. Wolski. 2003. Elementy fonetyki suprasegmentalnej w kontekście rozumienia tzw. tekstów autentycznych [The elements of suprasegmental phonetics in the context of authentic text comprehension]. In Dydaktyka fonetyki języka obcego II [Phonetics in Foreign Language Teaching 2], eds. W. Sobkowiak and E. Waniek-Klimczak, 79-85. Konin: Wydawnictwo PWSZ.

Presser, S., J. M. Rothgeb, M. P. Couper, J. T. Lessler, E. Martin, J. Martin and E. Singer (eds). 2004. Methods for Testing and Evaluating Survey Questionnaires. New Jersey: Wiley-Interscience.

Rajadurai, J. 2001. An Investigation of the Effectiveness of Teaching Pronunciation to Malaysian TESL Students. Forum 39: 10-17.

http:,,exchanges.state.gov,forum,vols,vol39,no3,p10.htm (date of access: 26 March, 2007).

Remiszewski, M. 2008. Lingua Franca Core: Picture Incomplete. In English Pronunciation Models: A Changing Scene, eds. K. Dziubalska-Kołaczyk and J. Przedlacka, 293-308. Bern: Peter Lang. 
Scheuer, S. 2008. Why Native Speakers are (Still) Relevant? In English Pronunciation Models: A Changing Scene, eds. K. Dziubalska-Kołaczyk and J. Przedlacka, 111130. Bern: Peter Lang.

Scheuer, S. in press. Why Polish and French students of English do not sound the same., Abstract 'Accents 2011': 33, paper presented at Accents' 2011: V International Conference on Native and Non-native Accents of English, University of Łódź, 1517 December 2011, http:,,filolog.uni.lodz.pl,accents2011,Abstracts.htm (date of access: 29 November, 2011).

Sifakis, N. S. and A.-M. Sougari. 2005. Pronunciation Issues and EIL Pedagogy in the Periphery: A Survey of Greek State School Teachers' Beliefs, TESOL Quarterly 39, 3: 467-488.

Sobkowiak, W. 2002. English speech in Polish eyes: What university students think about English pronunciation teaching and learning. In Accents and speech in teaching English phonetics and phonology, eds. E. Waniek-Klimczak and P. J. Melia, 177-96. Frankfurt: Peter Lang.

Sobkowiak, W. 2008. Why Not LFC? In English Pronunciation Models: A Changing Scene, eds. K. Dziubalska-Kołaczyk and J. Przedlacka (eds), 131-149. Bern: Peter Lang.

Stanojević, M.-M., V., Kabalin-Borenić and V., Josipović-Smojver. in press. Combining three types of data in studying attitudes to English as a Lingua Franca, Abstracts 'Accents 2011': 43, paper presented at Accents' 2011: V International Conference on Native and Non-native Accents of English, University of Łódź, 1517 December 2011, http:,,filolog.uni.lodz.pl,accents2011,Abstracts.htm (date of access: 29 November, 2011).

Szpyra-Kozłowska, J. 2008. Lingua Franca Core, Phonetic Universals and the Polish Context. In English Pronunciation Models: A Changing Scene, eds. K. DziubalskaKołaczyk and J. Przedlacka, 151-176. Bern: Peter Lang.

Szpyra-Kozłowska, J. 2004. Jaki model wymowy angielskiej? - dyskusji ciąg dalszy [What model of English pronunciation? - discussion continued]. In Dydaktyka fonetyki języka obcego IV [Phonetics in Foreign Language Teaching 4], eds. W. Sobkowiak and E. Waniek-Klimczak, 116-123. Konin: Wydawnictwo PWSZ.

Szpyra-Kozłowska, J., J. Frankiewicz and W. Gonet. 2002. Aspekty fonetyki angielskiej nauczane w polskich szkołach średnich [Aspects of English phonetics taught in Polish secondary schools]. In Dydaktyka fonetyki języka obcego I [Phonetics in Foreign Language Teaching 1], eds. W. Sobkowiak and E. Waniek-Klimczak, 9-27. Płock: Wydawnictwo PWSZ.

Szpyra-Kozłowska, J., J. Frankiewicz and R. Święcicki. 2006. The language laboratory and modern pronunciation pedagogy. In Dydaktyka fonetyki języka obcego $V$ [Phonetics in Foreign Language Teaching 5], eds. W. Sobkowiak and E. WaniekKlimczak, 285-303. Płock: Wydawnictwo PWSZ.

Szpyra-Kozłowska, J. and I. Pawlak. 2010. Listener attitudes to male and female voices. In Issues in Accents of English 2: Variability and norm, ed. E. Waniek-Klimczak, 115-132. Newcastle upon Tyne: Cambridge Scholars Publishing.

Timmis, I. 2002. Native-speaker norms and international English: A classroom view. ELT Journal 56, 3: 240-249. 
Tyurina, S. and L. Koltzova. in press. ESP teaching or does accent matter in professional discourse, Abstracts 'Accents 2011': 48, paper presented at Accents' 2011: V International Conference on Native and Non-native Accents of English, University of Łódź, 15-17 December 2011, http:,filolog.uni.lodz.pl,accents2011,Abstracts.htm (date of access: 29 November, 2011).

Vishnevskaya, G. 2008. Foreign Accent: Phonetic and Communication Hazards. In Issues in Accents of English, ed. E. Waniek-Klimczak, 235-251. Newcastle upon Tyne: Cambridge Scholars Publishing.

Walker, R. 1999. Proclaimed and perceived wants and needs among Spanish teachers of English, Speak Out! 24: 25-32.

Waniek-Klimczak, E. 1997. Context for Teaching English Phonetics and Phonology at Polish Universities and Colleges: A Survey. In Teaching English Phonetics and Phonology II: Accents' 97, ed. E. Waniek-Klimczak (ed.), 5-17. Łódź: Wydawnictwo Uniwersytetu Łódzkiego.

Waniek-Klimczak, E. and K. Klimczak. 2008. Target in Speech Development: Learners' Views. In English Pronunciation Models: A Changing Scene, eds. K. DziubalskaKołaczyk and J. Przedlacka, 229-249. Bern: Peter Lang.

Wrembel, M. 2002. Miejsce fonetyki języka angielskiego w szkole [The place of English language phonetics at school]. In Dydaktyka fonetyki języka obcego I [Phonetics in Foreign Language Teaching 1], eds. W. Sobkowiak and E. Waniek-Klimczak, 29-40. Płock: Wydawnictwo PWSZ.

Wrembel, M. 2003. Rola metakompetencji w akwizycji fonologii języka obcego w świetle badań dotyczących efektywności procesu nauczania wymowy [The role of metacompetence in the acquisition of foreign language phonology]. In Dydaktyka fonetyki języka obcego II [Phonetics in Foreign Language Teaching 2], eds. W. Sobkowiak and E. Waniek-Klimczak, 150-158. Konin: Wydawnictwo PWSZ.

Wrembel, M. 2005. The role of metacompetence in the acquisition of foreign language pronunciation. Unpublished Ph.D. dissertation. Poznań: Adam Mickiewicz University.

Wysocka, H. 2003. Czy i jak uczyć fonetyki języka obcego? [Shall we teach the phonetics of as foreign language, and how to do it?]. In Dydaktyka fonetyki języka obcego II [Phonetics in Foreign Language Teaching 2], eds. W. Sobkowiak, E. Waniek-Klimczak, 159-184. Konin: Wydawnictwo PWSZ.

Yeou. M. 2010. Pronunciation Instruction in Moroccan Higher Education: Students' Attitudes and Teachers' Views. In English Language Teaching and the Reform of University Studies, eds. S. Diouny and M. Yeou, 55-77. Publication de Faculté des Lettres: Chouaib Doukkali. Casblanca: Impremerie Najah, http:,ucd.academia.edu,MohamedYeou,Papers, 459522,Teaching_pronunciation_in_t he_New_Educational_Reform_Students_attitudes_and_current_practice (date of access: 29 November, 2011). 